\title{
Ovarian abscess with spontaneous vaginal drainage
}

Departamento de Obstetricia e Ginecologia da Universidade Estadual de Campinas

- Campinas, Brazil

The occurrence of a rare ovarian abscess, spontaneously drained through the vagina after an abdominal hysterectomy is described. The treatment was an oophorectomy. The various forms of primary ovarian abscess are discussed in connection with these observations. This case illustrates the need for adequate manipulation of the gonad during pelvic surgery in order to avoid parenchymal contamination and the subsequent formation of such abscesses.

UNITERMS: Ovarian abscess. Surgery. Fistula. Ovarian-to-vaginal.

\section{INTRODUCTION}

A $\mathrm{n}$ ovarian abscess is primarily an infectious process of the ovary which differs from the tuboovarian abscess in which involvement of the ovary is secondary to the tubes. An ovarian abscess was

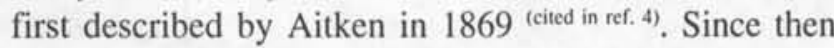
various cases of such abscesses have been documented ${ }^{(4)}$. The first instance of drainage through the vagina was reported in 1972 by Altman (1) followed by another case by Claman et $\mathrm{al}^{(2)}$ in 1991.

\section{CASE REPORT}

A 49 year-old Caucasian, widow, gravida 2, para 2, came for consultion complaining of a copious purulent and malodorous vaginal discharge. She had undergone a total abdominal hysterectomy for bleeding problems eleven months earlier. After surgery, she had fever and infection

\section{Address for correspondence:}

Gustavo A. de Souza

Rua Antonio Lapa, 303 - Cambui

Campinas/SP - Brasil - CEP 13025-240 of the surgical wound. On the 12th day after surgery she developed an abundant, purulent and fetid vaginal discharge which persisted until consultation. She received several courses of antibiotics which apparently led to the healing of the abdominal incision infection.

Clinical examination showed a patient in good general health with a median infra-umbilical surgical scar and an extended incisional hernia. Gynecological examination revealed an epithelized vaginal cuff. At right angles to this, there was a small orifice exuding a purulent secretion. The volume of this secretion increased when the lower abdomen was compressed. A cystic tumor with a maximal diameter of $4.0 \mathrm{~cm}$, attached to the vaginal dome was detected by bi-manual palpation. Pelvic ultrasonography performed three days later confirmed the presence of a cystic tumor, with well-defined, regular borders and internal echoes $(7.5 \times 5.5 \mathrm{~cm})$ (Fig. 1). Urine analysis and the hemogram were normal.

A laparotomy was performed and adherence of the omentum to the abdominal wall was observed. The remainder of the abdominal cavity was relatively free of other adherence. An enlarged right ovary with a smooth surface was observed, fixed to the vaginal dome while the tube presented a normal appearance. The left ovary apparently was normal. An oophorectomy was performed and during the dissection the abscess was opened at its communication with the vagina. The incisional hernia was also corrected. 


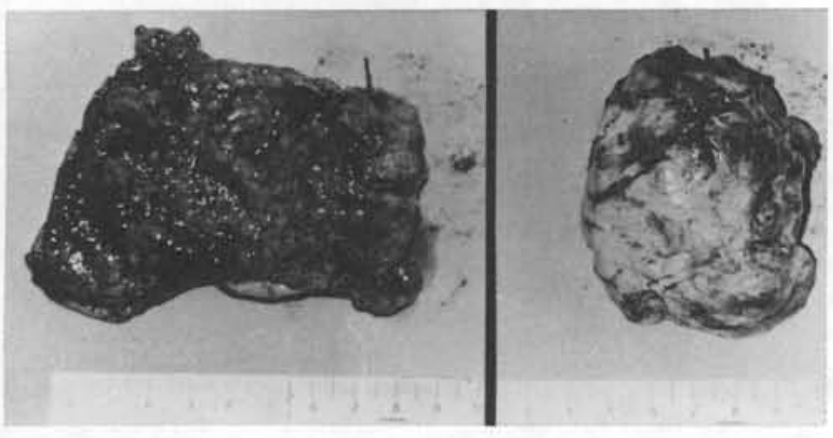

Figure 1 - Pelvic ultrasonography showing the ovary (cystic) close to the vaginal dome.

Amicacina and metronidazol were used as pre- and post-operatory antimicrobial therapy. A sample of pus from the abscess was collected and analyzed by microscopy and culturing. As a result of limited facilities, only the growth of aerobes was tested. Gram-positive cocci were observed by microscopy but no bacterial growth was detected in culture.

The post-operative period was uneventful. Examination of the ovary revealed a 5,0 $\times 3,0 \mathrm{~cm}$ cystic formation with a yellow granulous internal surface (Fig.2). Under the microscope, a large number of polymorphonuclear neutrophils, lymphocytes, plasmocytes and histiocytes were seen. The diagnosis was : "ovarian abscess".

\section{DISCUSSION}

Ovarian abscesses are rare and for this reason their etiology remains poorly understood. Wetcher and Dunn ${ }^{4}$ considered three possibilities to explain infection of the ovary:

1. The entry of bacteria into the parenchyma when the ovarian capsula is violated.

2. Contamination via the blood stream.

3. Contamination via the lymphatic system.

In their review of the literature, these authors indicated that this infection occurred in pregnant women (12 cases), in women using intrauterine devices ( 12 cases), in the post-

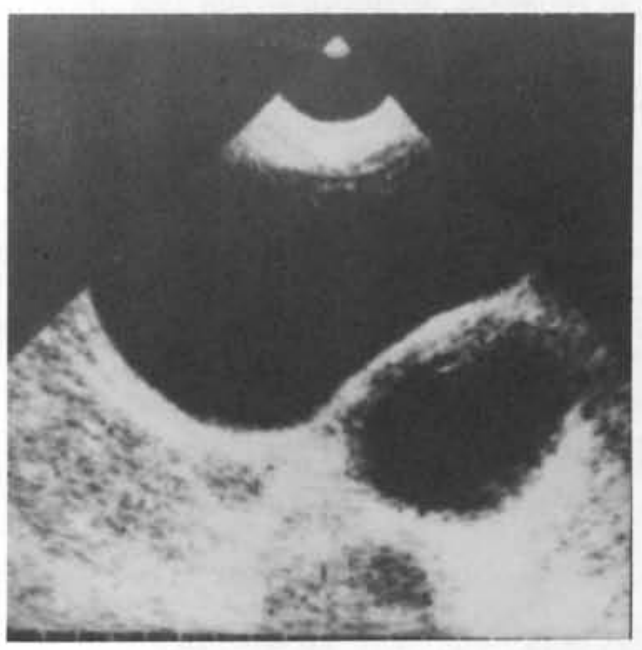

Figure 2 - The cystic ovary after the surgery (right) and opened (left).

operative period after pelvic surgery ( 78 cases) and in other cases classified as "miscellaneous" (57 cases).

The post-operative period is the most frequent and it is easy to control through prophylactic means. It does, however, need a precise diagnosis in patients recently submitted to pelvic surgery.

The invasion of bacteria in the ovarian parenchyma after surgery most likely results from lesion of the epithelium by artificial (surgical) or natural (ovulation and corpus luteum formation close to the time of surgery) means. Ledger et al ${ }^{(3)}$ considered the latter possibility to be the most common, since post-surgical ovarian abscesses occur most frequently in women submitted to vaginal surgery (considered to be contaminated) and in pre-menopausal women undergoing ovulation. These authors also observed that such abscesses occur more frequently in surgeries performed by residents. In this regard, inadequate hemostasis may also be a contributing factor since it is known that the hemoglobin released by red cells increases the virulence of gram-negative microorganisms ${ }^{3}$.

Ovarian abscesses are frequently accompanied by fever, abdominal pain, shivering, nausea, diarrhea, dysuria etc, albeit in some cases these symptoms may only appear later, up to 100 days or more after the pelvic surgery in a few cases $^{4}$.

Prophylaxis is still the most effective mean of avoiding this problem. The surgery must be performed properly, with well-controlled hemostasis and minimum manipulation of the area surrounding the ovary, particularly during pelvic surgery by, the vaginal route. It 
is advisable to avoid the use of blades or needles previously employed for skin or vaginal procedures, when work in the ovary is necessary. Fixing the tubes and ovary in the vaginal cuff should also be avoided, as it brings the gland into proximity with the contaminated vaginal environment. In addition, the infundibulopelvic ligament represents a weak structural support for the vagina.
The recommended treatment is to remove the affected gland or to drain the abscess in patients presenting a very compromised general condition. The surgery must be followed by proper antibiotic therapy effective against aerobic and anaerobic bacteria. Finally, the general care should be as for seriously ill patients, since fatalities have been attributed to these abscesses ${ }^{3}$.

\section{Resumo}

Descreve-se caso raro de abscesso ovariano, como complicação de histerectomia abdominal, e que drenou espontaneamente pela vagina. O tratamento realizado foi ooforectomia. Discute-se as várias formas de abscesso primário do ovário sendo que a pós operatória parece ser a mais comum. É necessário uma manipulação adequada da gônada em cirurgias pélvicas para se evitar a contaminaçăo do estroma, o que propicia a formaçăo do abscesso ovariano.

\section{REFERENCES}

1. Altman LC: Ovarian abscess and vaginal fistula. Obstet Gynecol 40:321-322,1972.

2. Claman P, Dover M, Saginur R, Tao $H$ and Orizaga M: Spontaneous ovarian-to-vaginal fistula: A case report. Am J Obstet Gynecol 164;71-72, 1991.
3. Ledger WJ, Campbell C, Taylor D and Willson JR: Adnexal abscess as a late complication of pelvic operations. Surg Gynecol Obstet 127:973-978,1969.

4. Wetchler SJ and Dunn LJ: Ovarian abscess. Report of a case and review of the literature. Obstet Gynecol Surv 40:476485,1985 . 